\title{
Sosialisasi, Penyuluhan, dan Pelatihan Budidaya Jahe Merah di Dusun Pelem, Desa Wonorejo, Kecamatan Jatiyoso, Kabupaten Karanganyar
}

\author{
Bambang Pujiasmanto*, Eddy Triharyanto, Hery Widijanto, Pardono, Puji Harsono, \\ Sulandjari
}

Fakultas Pertanian, Universitas Sebelas Maret

*Coresponding Author: bambang_p56@staff.uns.ac.id.

\begin{abstract}
ABSTRAK
Jahe merah merupakan tanaman obat yang bermanfaat, baik untuk kesehatan maupun makanan olahan. Tujuan kegiatan ini memberikan pengetahuan budidaya jahe merah mulai perbenihan sampai cara budidaya Jahe Merah. Kegiatan dilakukan di Dusun Pelem, Desa Wonorejo, Kecamatan Jatiyoso, Kabupaten Karanganyar. Metode yang digunakan yaitu penyuluhan partisipatif, dimana para petani secara langsung terlibat, baik dalam sosialisasi maupun penyuluhan. Kegiatan dilaksanakan dengan beberapa tahapan sebagai berikut: 1) Koordinasi dengan tokoh masyarakat dan petani mitra; 2) Sosialisasi pelaksanaan kegiatan; 3) Penyuluhan tentang budidaya jahe merah, dan 4) Pelatihan budidaya jahe merah di polybag. Hasil kegiatan menunjukkan bahwa petani sebagai objek sangat tertarik dan berminat dalam budidaya jahe merah, yang tercermin dari keaktifan dalam berdiskusi maupun dalam melaksanakan pelatihan. Kondisi tanah dan agroklimat yang sesuai mendukung budidaya jahe merah di Dusun Pelem, sehingga dapat meningkatkan pendapatan petani.
\end{abstract}

Kata kunci: jahe merah, budidaya, partisipatif, pendapatan, petani

\section{ABSTRACT}

Red ginger is a useful medicinal plant.. The purpose of this activity is to provide knowledge of red ginger cultivation. The activity was held in Pelem Hamlet, Wonorejo Village, Jatiyoso District, Karanganyar. The method used in this community service activity is by participatory counseling. The activities are carried out in the following stages: 1) coordination with community leaders and partner farmers; 2) socialization of the implementation of activities; 3) counseling on the cultivation of red ginger, and 4) training on the cultivation of red ginger in polybags. The results of the activity showed that farmers as objects are very interested and interested in the cultivation of red ginger, reflected in the activeness in discussing and in carrying out training. Suitable soil and agroclimate conditions support the cultivation of red ginger in Pelem Hamlet, so as to increase farmers' income.

Keywords: red ginger, cultivation, participative, income, farmer

\section{PENDAHULUAN}

Jahe merupakan salah satu tanaman obat. Jahe merupakan tanaman tropis yang dapat tumbuh di daerah iklim panas maupun lembab. Tanaman jahe dibudidayakan di AS, India, Cina, Nepal, Bangladesh, Nigeria, Taiwan, Jamaika, dan Indonesia (Syafitri et al., 2018). Di Indonesia jahe dapat dibedakan menjadi jahe gajah/badak, jahe emprit dan jahe merah (Pramono, 2020). Jahe merah (Zingiber officinale Rosc.) termasuk dalam keluarga Zingiberaceae yang merupakan tanaman obat, rumpun batang buatan, dan umumnya dapat dipanen pada umur 8-12 bulan (Gati \& Mariska, 2017; Soeparjono, 2016). Jahe merah banyak digunakan untuk bumbu, obat tradisional, minuman penyegar, dan sebagai komoditas ekspor (Friska \& Daryono, 2017). Jahe merah dan jahe emprit mengandung minyak atsiri cukup besar (1,5-3,8\% berat kering), sehingga cocok digunakan untuk ramuan obat atau diekstrak minyak atsirinya (Febriani et al., 2018). Minyak atsiri mengandung zat aktif yang mempunyai khasiat mencegah dan mengobati beberapa penyakit, baik yang ringan maupun penyakit berat, misalnya: masuk angin, pusing, rematik, mual-mual, impoten, kanker, maupun 
penyakit jantung (Aryanta, 2019). Identifikasi terdapat senyawa kimia dalam ekstrak jahe merah dan cabai jawa yang mengandung senyawa aktif berkhasiat untuk penyakit kanker (Ekowati et al., 2011). Dalam bidang makanan, saat ini dikenal berbagai jenis olahan jahe, misal permen jahe, manisan jahe, minuman instan, asinan jahe, kopi jahe, sirup jahe, dan beberapa produk olahan lain (Koswara \& Diniari, 2016).

Produksi jahe merah di Indonesia masih sangat kecil dibandingkan negara lain. Produktivitas dan kandungan senyawa aktif dalam rimpang jahe dipengaruhi sistem budidaya (monokultur/tumpang sari/agroforestry) dan kondisi lingkungan (ketinggian tempat, iklim, dan tanah) (Azizah et al., 2019). Dalam budidaya jahe merah dibutuhkan media yang sesuai untuk pertumbuhan. Keberhasilan budidaya jahe merah ditentukan oleh kemampuan tanaman dalam memproduksi hasil panen. Penggunaan media tanam yang tepat dapat meningkatkan ketersediaan unsur hara untuk pertumbuhan jahe merah, sehingga produksi bisa optimal (Aidin $e t$ $a l ., 2016)$. Penggunaan pupuk organik, interaksi pupuk organik dan komposisi media sangat mempengaruhi parameter pertumbuhan dan hasil rimpang jahe merah, yaitu tinggi tanaman, jumlah daun, jumlah tunas, berat segar rimpang, berat biomassa, kadar zingeron, dan kadar oleoresin (\%) (Soeparjono, 2016). Pada penelitian dengan media tanah dan pupuk kandang, penggunaan klon jahe merah menunjukkan produksi yang lebih tinggi dibandingkan jahe gajah dan jahe emprit disebabkan jahe merah mampu menghambat berkembangnya penyakit berupa layu bakteri (Fauzia \& Nurcahyanti, 2020).

Pengetahuan budidaya jahe merah mulai dari perbenihan sampai panen, beserta syaratsyarat pertumbuhannya banyak yang belum diketahui oleh masyarakat. Dengan demikian perlu dilakukan sosialisasi. Perumusan masalah: 1. Petani Dusun Pelem banyak yang belum mengetahui secara rinci budidaya Jahe Merah. 2. Bagaimana syarat tumbuh tanaman jahe merah yang tepat, agar petani tidak mengalami gagal panen. Kegiatan pengabdian bertujuan untuk memberikan pengetahuan budidaya jahe merah mulai perbenihan sampai siap tanam dan memberikan pengetahuan tentang syarat tumbuh sampai cara-cara budidaya jahe merah yang sesuai dengan Good Agriculture Practices (GAP). Manfaat dari kegiatan ini diharapkan potensi lahan subur di Dusun Pelem, Wonorejo,
Jatiyoso dapat dikembangkan menjadi tanaman obat, khususnya tanaman obat jahe merah. Budidaya tanaman jahe merah yang dilakukan diharapkan dapat meningkatkan pendapatan dan kesejahteraan petani.

\section{METODE}

Pelaksanaan kegiatan mulai bulan Februari 2020 sampai bulan Juli 2020. Lokasi pengabdian di Dusun Pelem, Desa Wonorejo, Kecamatan Jatiyoso. Bahan yang digunakan antara lain benih/bibit jahe merah (Zingiber officinale Rubrum) dengan varietas Sunti, tali raffia, karung/polybag, tanah, dan pupuk kandang sapi. Alat yang digunakan berupa cangkul, sabit, alat pengukur suhu dan kelembaban relatif (hygrotermometer), alat pengukur cahaya (luxmeter) dan meteran. Metode yang digunakan dalam kegiatan pengabdian masyarakat ini adalah penyuluhan partisipatif, dimana para petani secara langsung terlibat, baik dalam sosialisasi maupun penyuluhan. Metode ini dicirikan dengan terlibatnya secara langsung masyarakat dalam kegiatan yang dilakukan (Rubiantoro \& Haryanto, 2013). Kegiatan pengabdian masyarakat ini dilaksanakan dengan beberapa tahapan sebagai berikut: 1) koordinasi dengan tokoh masyarakat dan petani mitra ;2) sosialisasi pelaksanaan kegiatan di tingkat desa; 3) penyuluhan tentang budidaya jahe merah, dan 4) pelatihan budidaya jahe merah di polybag.

\section{HASIL DAN PEMBAHASAN}

Kecamatan Jatiyoso berada pada ketinggian 516 mdpl terletak di sebelah selatan dari kota Kabupaten Karanganyar. Batas-batas wilayah di Kecamatan Jatiyoso, yaitu sebelah utara berbatasan dengan Kecamatan Tawangmangu, sebelah timur berbatasan dengan Kecamatan Jatipurna (Kabupaten Wonogiri), sebelah selatan dengan Kecamatan Girimarto (Kabupaten Wonogiri), sebelah barat dengan Kecamatan Jumapolo. Secara administrasi Kecamatan Jatiyoso merupakan bagian wilayah dari Kabupaten Karanganyar yang memiliki orbitasi jarak 28,5 km dari Kabupaten Karanganyar. Kecamatan Jatiyoso terdiri atas 9 desa/kelurahan yang pemerintahannya berpusat di Desa Jatiyoso. Adapun desa yang masuk dalam pemerintahan Kecamatan Jatiyoso, yaitu: 1. Beruk, 2. Jatisawit, 3. Jatiyoso, 4. Karangasari, 5. Petung, 6. Tlobo, 7. Wonokeling, 
8. Wonorejo, dan 9. Wukirsawit. Jumlah penduduk Kecamatan Jatiyoso yaitu 40.709 jiwa. Jenis tanah di Jatiyoso terdiri dari: litosol coklat kemerahan, komplek andosol coklat, dan litosol. Komoditas pertanian yang menonjol yaitu cengkeh, pisang, sayuran, dan tanaman obat. Lembaga keuangan yang berada di Jatiyoso meliputi BRI, PD. BPR, dan BKK. Desa Jatiyoso memiliki 2 pasar yakni pasar desa Tlobo dan pasar desa Karangsari, transportasi angkutan desa, dan mempunyai 1 unit Puskesmas. Penggunaan lahan terdiri dari sawah, pekarangan, tegal/kebun, tambak/kolam, dan perkebunan. Lahan yang ada sangat cocok dikembangkan tanaman obat. Sehingga peningkatan potensi pertanian pada sektor pertanian diharapkan mampu menopang dan mempercepat laju dan pertumbuhan ekonomi Jatiyoso dan sekaligus mereduksi tingkat kemiskinan.

Tahapan pengabdian yang dilakukan di Dusun Pelem, Wonorejo, Kecamatan Jatiyoso, Kabupaten Karanganyar dilakukan dalam 3 tahap yaitu: koordinasi, sosialisasi dan penyuluhan, serta pelatihan budidaya jahe merah. Koordinasi dengan tokoh masyarakat Dukuh Pelem dan petani mitra dilakukan untuk menentukan waktu kegiatan. Kegiatan ini dilakukan pada 20 Mei 2020. Koordinasi ini penting karena tidak mudah mensinkronkan waktu yang longgar antara petani dan tim pengabdian. Hasil koordinasi disepakati waktu pelaksanaan sosialisasi, penyuluhan dan pelatihan budidaya jahe merah. Dalam kegiatan koordinasi juga dilakukan survei kondisi lahan di lokasi pengabdian. Hasil survei dapat menentukan lokasi dimana tanaman jahe merah akan dibudidayakan (Gambar 1).

Sosialisasi kegiatan pengabdian dan penyuluhan tentang budidaya jahe merah dilaksanakan pada 21 Juli 2020, bertempat di rumah bapak Kepala Dusun Pelem. Pada kegiatan ini, selain mengundang petani juga menghadirkan kepala desa dan perangkat desa maupun kecamatan. Materi yang diberikan pada sosialisasi antara lain: latar belakang, tujuan dan manfaat kegiatan bagi petani, terutama dalam meningkatkan pendapatan petani dengan menanam jahe merah. Dalam sosialisasi juga diberikan penjelasan tentang alasan pemilihan Dusun Pelem sebagai lokasi kegiatan, yaitu kondisi tanah dan agroklimatnya yang sesuai untuk tanaman jahe merah (Gambar 2). Jahe merah cocok dibudidayakan di daerah dengan tanah subur, gembur, banyak mengandung bahan organik dan berdrainase baik. Agroklimat juga menjadi faktor yang penting dalam produksi dan kualitas dari rimpang jahe merah (Azizah et al., 2019).

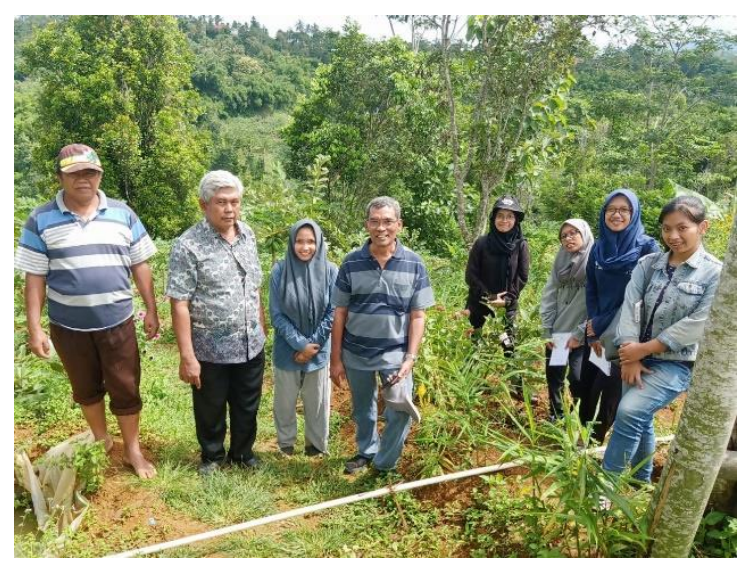

Gambar 1. Survei lokasi kegiatan untuk budidaya tanaman jahe merah

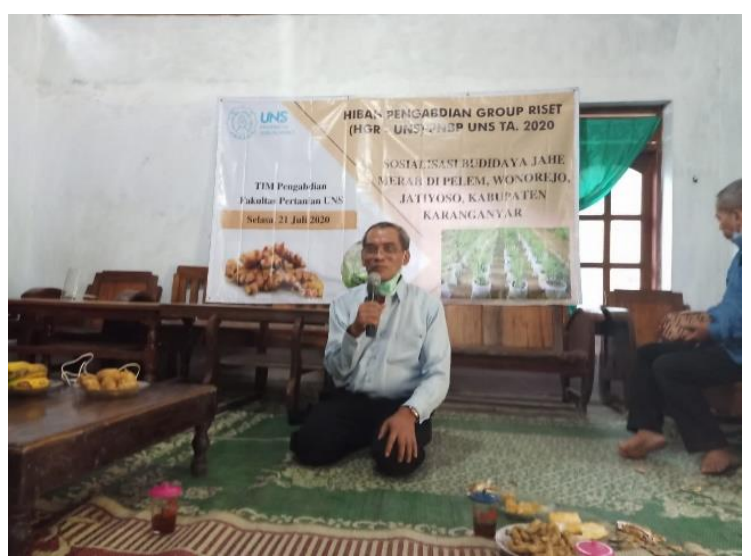

Gambar 2. Sosialisasi kegiatan oleh ketua Tim Pengabdian

Kegiatan penyuluhan tentang budidaya jahe merah dilakukan setelah sosisalisasi kegiatan pengabdian. Meteri penyuluhan disampaikan oleh tim pengabdian secara bergantian (Gambar 3). Materi yang diberikan antara lain penyiapan benih, penyiapan media tanam, penanaman, pemeliharaan, pengendalian HPT, dan pemanenan. Pemilihan benih jahe merah dilakukan untuk menghasilkan benih yang bermutu. Benih bermutu dapat meliputi mutu fisik, mutu genetik mutu fisiologi (Sukarman et al., 2020). Media tanam bisa dilakukan di lapangan/kebun, maupun dalam polybag. Pemupukan dilakukan untuk menambah unsur hara bagi pertumbuhan tanaman jahe merah. Hasil penelitian menunjukkan bahwa dengan penambahan pupuk $\mathrm{N} 216 \mathrm{~kg} / \mathrm{ha}$ dapat memberikan hasil rimpang yang maksimal (Peña-Gutiérrez et al., 2019). 
Dalam penyuluhan dijelaskan tentang penyakit layu bakteri pada jahe merah. Penyakit ini dapat menyerang batang maupun rimpang tanaman, sehinga akan menyebabkan tanaman jahe merah menjadi layu, daun menguning, hingga kelamaan mati (Fauzia \& Nurcahyanti, 2020).

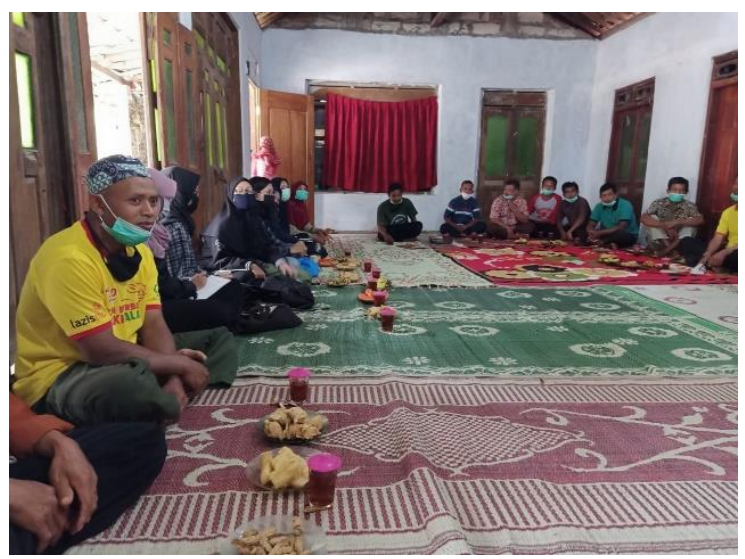

Gambar 3. Penyampaian materi penyuluhan tentang budidaya jahe merah

Kegiatan pelatihan budidaya jahe merah dilaksanakan pada tanggal 23 Juli 2020, bertempat di Dusun Pelem (Gambar 4). Pelatihan ini diikuti petani-petani yang sudah menerima penyuluhan tentang budidaya jahe merah. Bibit yang digunakan berasal dari benih yang tidak mengalami dormansi, sehingga cepat dapat bertunas. Media tanam untuk menanam jahe merah yang memiliki unsur hara cukup baik hara makro $(\mathrm{N}, \mathrm{P}, \mathrm{K})$ maupun mikro $(\mathrm{Cl})$. Penanaman dilakukan setelah benih atau rimpang jahe merah bertunas. Kegiatan yang dipraktikkan dalam pelatihan ini adalah penyiapan bibit, penyiapan media tanam dan penanaman bibit jahe merah. Dalam penyiapan bibit jahe merah, harus dipilih rimpang yang daya tumbuhnya tinggi, kadar air yang cukup/tidak keriput, dan cukup umur (Sukarman et al., 2020).

Pengunaan media tanam yang tepat akan menunjang pertumbuhan dan produksi jahe merah, karena media tanam merupakan pensuplai unsur hara bagi pertumbuhan (Aidin $e t$ al., 2016). Media tanam yang tepat merupakan salah satu syarat keberhasilan budidaya tanaman khususnya budidaya dalam wadah atau polybag (Aidin et al., 2016). Dalam penyiapan media tanam, ditambahkan pupuk organik sebagai campuran. Penambahan bahan organik dalam media tanam dengan campuran bahan organik perlu dilakukan, karena bahan organik dapat menyediakan unsur nutrisi untuk tanaman (Soeparjono, 2016),

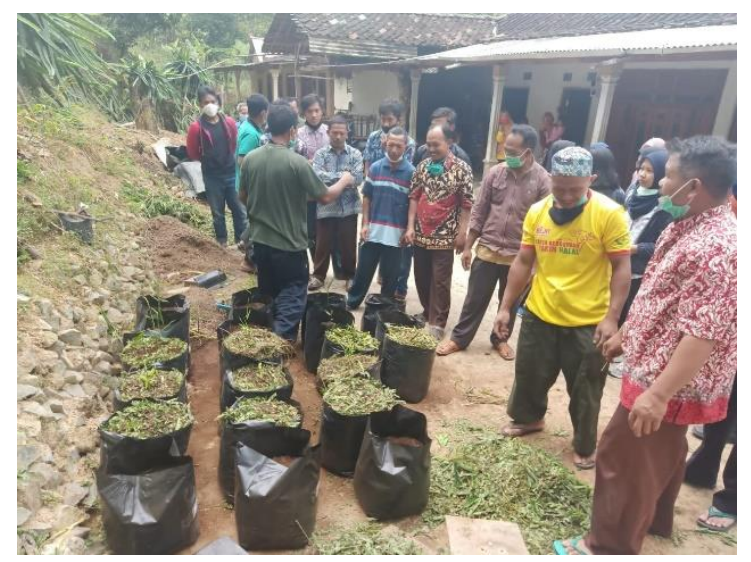

Gambar 4. Praktek menyiapkan media tanam dan penanaman jahe merah di polybag

\section{KESIMPULAN}

Kesimpulan yang dapat diperoleh dari kegiatan pengabdian ini adalah semua tahapan kegiatan (sosialisasi, penyuluhan dan pelatihan) tentang budidaya tanaman jahe merah dapat dilaksanakan dengan baik. Petani sebagai objek sangat tertarik dan berminat dalam budidaya jahe merah, tercermin dari keaktifan dalam berdiskusi maupun dalam melaksanakan pelatihan. Materi yang diberikan dalam penyuluhan dan pelatihan sangat membantu petani untuk melakukan budidaya jahe merah, sehingga diharapkan akan memperoleh produksi yang optimum. Kondisi tanah dan agroklimat yang sesuai diharapkan semakin mendukung budidaya jahe merah di Dusun Pelem dan meningkatkan pendapatan petani.

\section{UCAPAN TERIMA KASIH}

Ucapan terima kasih disampaikan kepada Rektor Universitas Sebelas Maret (UNS) yang telah memberikan dana untuk kegiatan ini melalui PNBP 2020, skim HRG Pengabdian.

\section{DAFTAR PUSTAKA}

Aidin, A., Sahiri, N., \& Madauna, I. (2016). The effect of rhizome types and the composition of planting media on the growth of red ginger(Zingiber Officinale Rosc.). J. Agrotekbis, 4(4), 394-402.

Aryanta, I. W. R. (2019). Manfaat jahe untuk kesehatan. Widya Kesehatan, 1(2), 39-43. https://doi.org/10.32795/widyakesehatan. v1i2.463

Azizah, N., Purnamaningsih, S. L., \& Fajriani, S. (2019). Land characteristics impact productivity and quality of ginger 
(Zingiber officinale rosc) in Java, Indonesia. Agrivita, 41(3), 439-449. https://doi.org/10.17503/agrivita.v41i3.2 321

Ekowati, H., Septiyaningsih, \& Harwoko. (2011). An extract of Zingiber officinale and Piper retrofractum combination and its effect to cancer cell line. Indonesian Journal of Cancer Chemoprevention, 2(1), 173. https://doi.org/10.14499/indonesianjcanc hemoprev2iss 1pp173-181

Fauzia, Y. F., \& Nurcahyanti, S. D. (2020). Ketahanan tiga klon jahe (Zingiber officinale Rosc.) terhadap penyakit layu bakteri (Ralstonia solanacearum). Jurnal Proteksi Tanaman Tropis, 1(2), 62-69. https://doi.org/10.19184/jptt.v1n2.18013

Febriani, Y., Riasari, H., Winingsih, W., Aulifa, L., \& Permatasari, A. (2018). Potensi pemanfaatan ampas jahe merah (Zingiber officinale Roscoe) sebagai obat analgetik. Indonesian Journal of Pharmaceutical Science and Technology, 1(1), 57-64.

Friska, M., \& Daryono, B. S. (2017). Karakter fenotip jahe merah (Zingiber officinale Roxb. var rubrum Rosc.) hasil poliploidisasi dengan kolkisin. $A l$ Kauniyah: Jurnal Biologi, 10(2), 91-97. https://doi.org/10.15408/kauniyah.v10i2. 4813

Gati, E., \& Mariska, Ik. (2017). Perbanyakan cepat jahe merah melalui teknik kultur jaringan. In Buletin Penelitian Tanaman Rempah dan Obat (Vol. 3, Issue 1, pp. 3538).

https://doi.org/10.21082/bullittro.v3n1.19 88.33-38

Koswara, S., \& Diniari, A. (2016). Peningkatan mutu dan cara produksi pada industri minuman jahe merah instandi Desa Benteng, Ciampea, Bogor. Agrokreatif Jurnal Ilmiah Pengabdian Kepada Masyarakat, $\quad 149$. https://doi.org/10.29244/agrokreatif.1.2.1 49-161

Peña-Gutiérrez, A. M., Pérez-Flores, J., RiveroBautista, N. del, \& Santos, A. O. L. (2019). Effect of fertilization on yield and NPK contents in red ginger. Journal of Experimental Agriculture International, 30(6), $1-8$. https://doi.org/10.9734/jeai/2019/46151

Pramono, S. (2020). Utilisation and functional components evaluation of ginger. In Ginger Cultivation and Its Antimicrobial and Pharmacological Potentials (pp. 114). https://doi.org/10.5772/intechopen.88940

Rubiantoro, E. A., \& Haryanto, R. (2013). Bentuk keterlibatan masyarakat dalam upaya penghijauan pada kawasan hunian padat di kelurahan serengan - Kota Surakarta. Jurnal Pembangunan Wilayah \& Kota, 9(4), 416. https://doi.org/10.14710/pwk.v9i4.6679

Soeparjono, S. (2016). The effect of media composition and organic fertilizer concentration on the growth and yield of red ginger rhizome (Zingiber officinale Rosc.). Agriculture and Agricultural Science Procedia, 9, 450-455. https://doi.org/10.1016/j.aaspro.2016.02. 162

Sukarman, S., Rusmin, D., \& Melati, M. (2020). Pengaruh lokasi produksi dan lama penyimpanan terhadap mutu benih jahe (Zingiber officinale L.). Jurnal Penelitian Tanaman Industri, 14(3), 119. https://doi.org/10.21082/jlittri.v14n3.200 8.119-124

Syafitri, D. M., Levita, J., Mutakin, M., \& Diantini, A. (2018). A review: is ginger (Zingiber officinale var. Roscoe) potential for future phytomedicine? Indonesian Journal of Applied Sciences, 8(1), 8-13. https://doi.org/10.24198/ijas.v8i1.16466 